\title{
Integration of 3D Seismic and Well log Data In the Optimal Reservoir Characterisation of EMI Field, Offshore Niger Delta Oil Province, Nigeria
}

\author{
'Oyedele, K.F, ${ }^{2}$ Ogagarue, D.O and Mohammed, D.U \\ 'Department of Geosciences, University of Lagos, Nigeria \\ 2Department of Earth Sciences, Federal University of Petroleum Resources, Effurum, Delta \\ State \\ Kayode.oyedele@gmail.com \\ dogagaru@yahoo.com
}

\begin{abstract}
Seismic and Petro-physical evaluation of EMI field revealed typical structural features of the Niger Delta, namely the roll over anticlines and growth faults with a promising good hydrocarbon accumulation. The extensive faults F2, F3 and F4, which were structure building faults, support suspected hydrocarbon prospects (P2 and P3) which could be explored in the future. The deeper of the two horizons mapped in this study, have better structures for hydrocarbon accumulation with supporting growth faults. The shallower horizon, $\mathrm{H} 1$ does not have any faults intersecting it. The two horizons marked the tops of reservoir sands in the field and they both correspond to sequence boundaries as observed on the seismic sections. The Petro-physical values - the Porosity, Net to Gross, Water saturation, Hydrocarbon saturation that were calculated from the POWERLOG software, were almost ideal for the Niger Delta reservoir sands with average porosity values of 0.25 , water saturation of 0.42 and average Net to Gross value of 0.85 . The lower the water saturation, the higher the hydrocarbon saturation in the reservoir sand, and also the higher the net to gross value, the higher the hydrocarbon saturation.
\end{abstract}

Keywords: Petro-physical, sequence boundary, hydrocarbon saturation, growth fault.

\section{INTRODUCTION}

The present local and global increase in demand for energy has placed both pressure and greater challenge to increase energy supply. The advancement in computational technology to evaluate the probability of hydrocarbon presence in any basin has reduced the risk factor associated with hydrocarbon exploration. In Nigeria, oil almost constitutes exclusively the revenue base for national development and as such it demands greater efforts from both the Government and the research institutions to ensure that this non-renewable resource is adequately and optimally tapped.

Niger Delta province has commercial accumulation of oil and gas. The production of oil and gas is from accumulation in the pore spaces of reservoir rocks usually sandstone, limestone and dolomite. The formation is characterised by alternating sandstone and shale units varying in thickness from $100 \mathrm{ft}$ to 1500ft. (Doust and Omatsola,1990 Short and
Stauble, 1967). The sand in this formation is mainly hydrocarbon reservoir with shale providing lateral and vertical seal. Reservoir characterisation and subsurface geological mapping are perhaps the most important tools used to explore for undiscovered hydrocarbons and to develop proven hydrocarbon reserves. As field is developed from its initial discovery, a large volume of well, seismic, and production data are obtained. With the integration of these data sets, the accuracy of the subsurface interpretation is improved through time.

3D seismic interpretation often requires extrapolating well data far from the area of interest, crossing faults, sequence boundaries, and other discontinuities (Sheriff and Geldart, 1995). Well data provides a variety of information describing the lithology (including the mineralogy, porosity, and perhaps even the morphology of the pore spaces), the fluid content (sometimes related to logged conditions, in virgin reservoirs conditions), and detailed depth constraints 
on geologic horizons (Weber and Daukoru, 1975). Seismic stratigraphy establishes a stratigraphic framework and burial history within which one identifies geologic ages, environments of deposition and depositional body types. The facies provides a basis for identifying lithology, porosity/permeability, fluid content, and fractures and provides insight into source rocks and seals. (Bryant,1996).

In order to characterize EMI field, seismic sections and composite well logs (which include the Gamma Ray, Resistivity, Sonic and Neutron Density logs) were examined and interpreted with a view to unravel the hydrocarbon in place.

Geology of the area: The Niger Delta is situated in southern Nigeria (Fig. 1) between latitudes $3^{\circ} \mathrm{N}$ and $6^{\circ} \mathrm{N}$ and longitude $5^{\circ} \mathrm{E}$ and $8^{\circ} \mathrm{E}$ (Nwachukwu, and Chukwura, 1986). It covers an area of 75,000 sqkm. It is bounded to the west and northwest by the western African shield, which terminates at the Benin hinge line and to the east, by the Calabar hinge line. The Anambra basin and Abakaliki anticlinorium mark its northern limit. To the south, it is bounded by the gulf of Guinea.

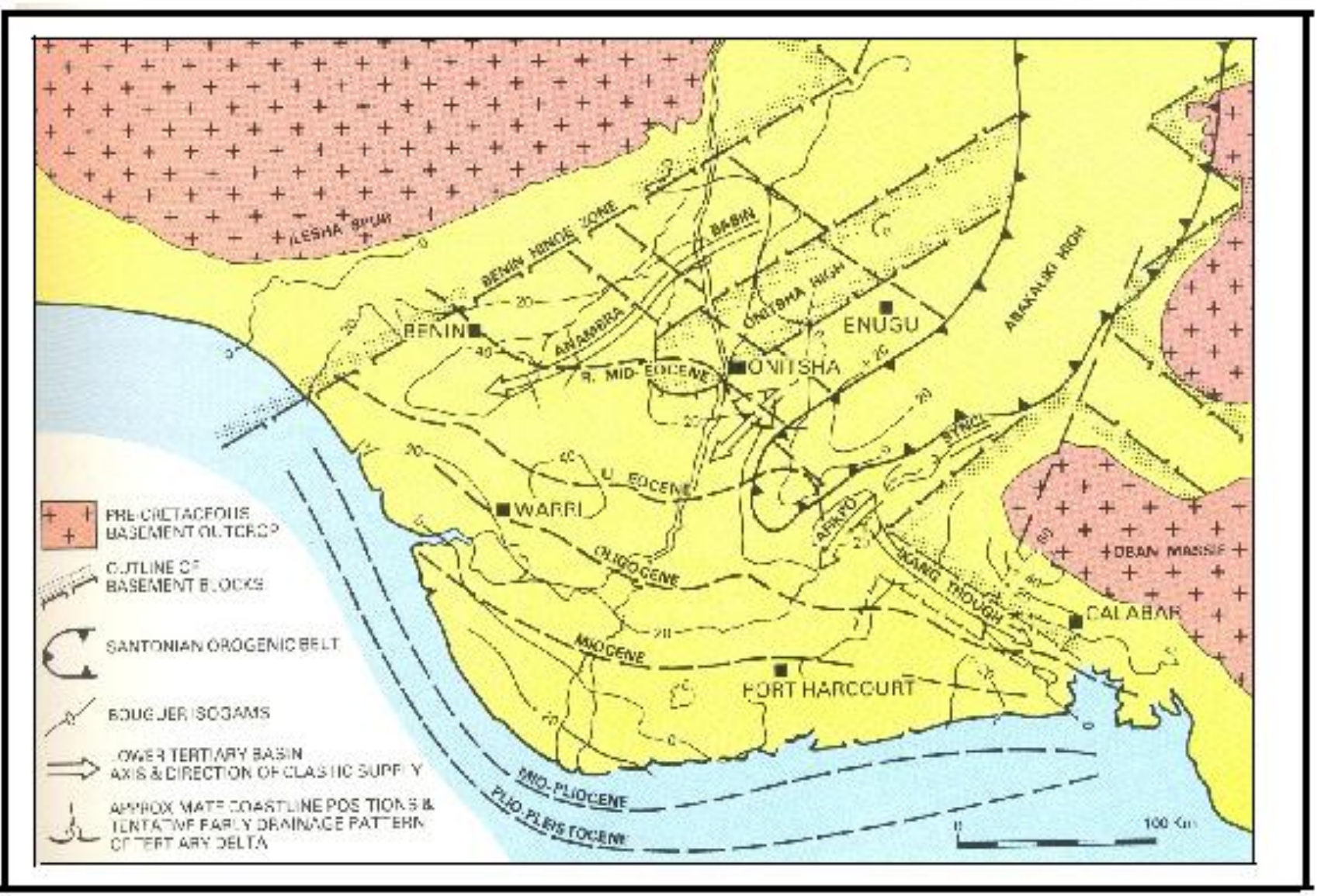

Fig 1: Geological map of Niger Delta

The Niger Delta Basin to date is the most prolific and economic sedimentary basin in Nigeria by virtue of the size of petroleum accumulations, discovered and produced as well as the spatial distribution of the petroleum resources to the Onshore, Continental shelf through deepwater terrains. Intensive exploration efforts over the last 35 years in and around the Niger Delta in particular has led to a succession of significant discoveries, notably the Bonga, Agbami/Ekoli and Akpo discoveries in Nigeria and Zafiro and Alba in Equatorial Guinea. However, the full potential of the continental slope and rise seaward of the shelf break is only recently becoming apparent, with a number of exploration programs having resulted in world-class discoveries being made in recent years. 
From the Eocene to the present, the delta has prograded southwestward, forming depobelts that represent the most active portion of the delta at each stage of its development (Doust and Omatsola, 1990).These depobelts form one of the largest regressive deltas in the world with an area of some $300,000 \mathrm{Km}^{2}$ (Kulke, 1995 and Chukwueke, 1997), a sediment volume of $500,000 \mathrm{Km}$, and a sediment thickness of about $12 \mathrm{~km}$ in the basin depocenter.

The Niger Delta province contains only one identified petroleum system (Kulke, 1995,Ekweozor, and Daukoru, 1994); this system is referred to here as Tertiary Niger Delta (Akata-Agbada) Petroleum System. The maximum extent of the petroleum system is defined by the aerial extent of the fields and contains known reserves (cumulative production plus proved reserves) of 34.5 Billion Barrel of Oil BBO) and 93.8 Trillion Cubic Feet of $\mathrm{Gas}^{2}$ (TCFG) (Petroconsultants, 1996).

\section{METHODOLOGY}

The data used in this study consist of 42 three dimensional Seismic reflection data, comprising (15 in-lines and 27 cross-lines); suite of geophysical wireline logs for the six wells; a base map, check-shot data and bio-stratigraphic data. The evaluation study was carried out in two phases - Seismic data interpretation and Petro-physical data analysis. TimeStructure and Depth-Structure maps were generated from the seismic sections while formation parameters such as porosity, water saturation, and net to gross were calculated from petro-physics. The procedures taken for both phases were carefully done with consideration of the objectives of the study.

\section{Data processing and interpretation}

Picking of Horizons: A horizon represents a mappable isochronous geologic time surface. It is the interface between two different rock layers. It is associated with continuous and reliable reflection on the sections that appear over a large area. Two horizons were picked which marked the top of sands $A$ and C. (figs 2 to 5 ). Identification of faults on the seismic section was based on the following criteria:
a. Reflection discontinuity at fault plane
b. Vertical displacement of reflection
c. Mis-closures in tying reflections around loops.
d. Abrupt termination of events
e. Overlapping of reflections
f. Change in pattern of events across the faults

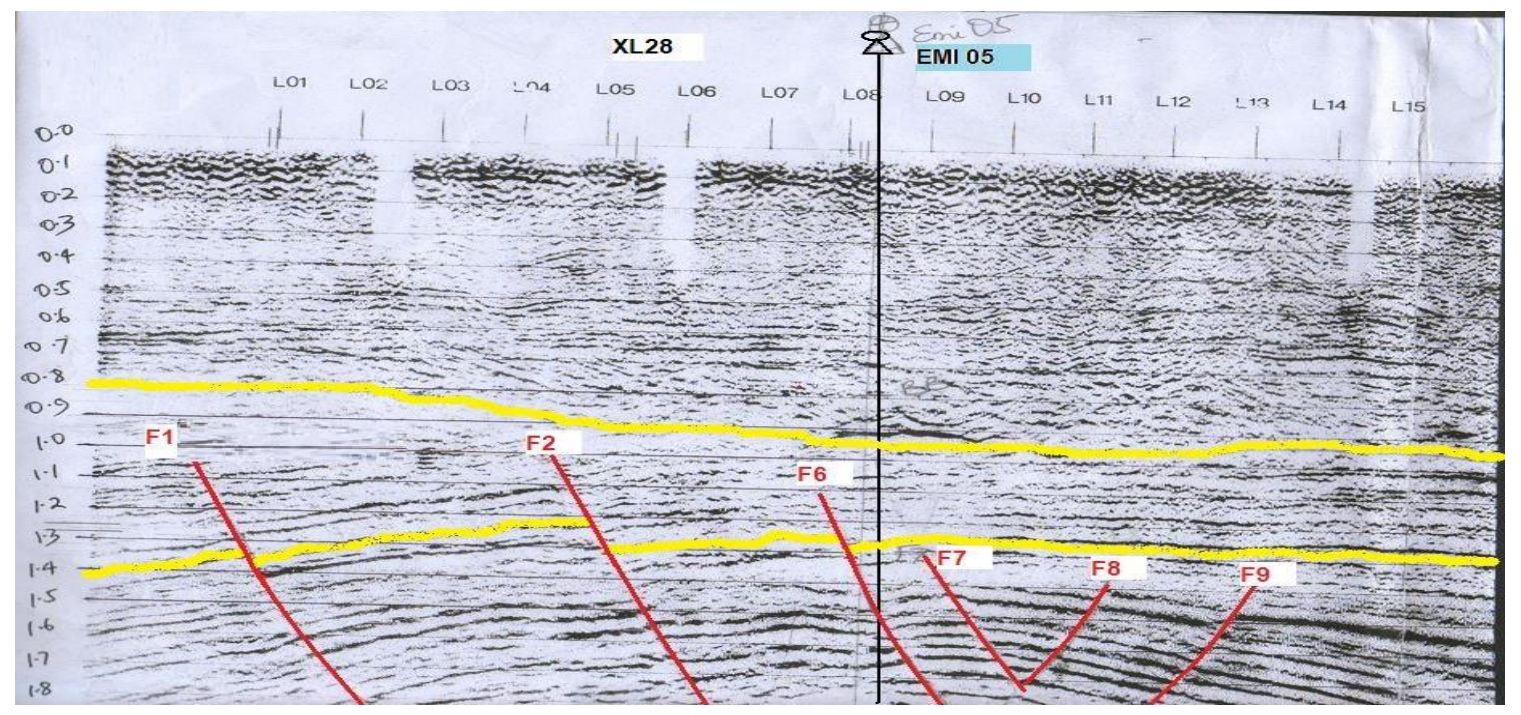

Fig.2: Seismic cross-line 28 showing well 05, faults picked and horizons 1 and 2 
Am. J. Sci. Ind. Res., 2013, 4(1): 11-21

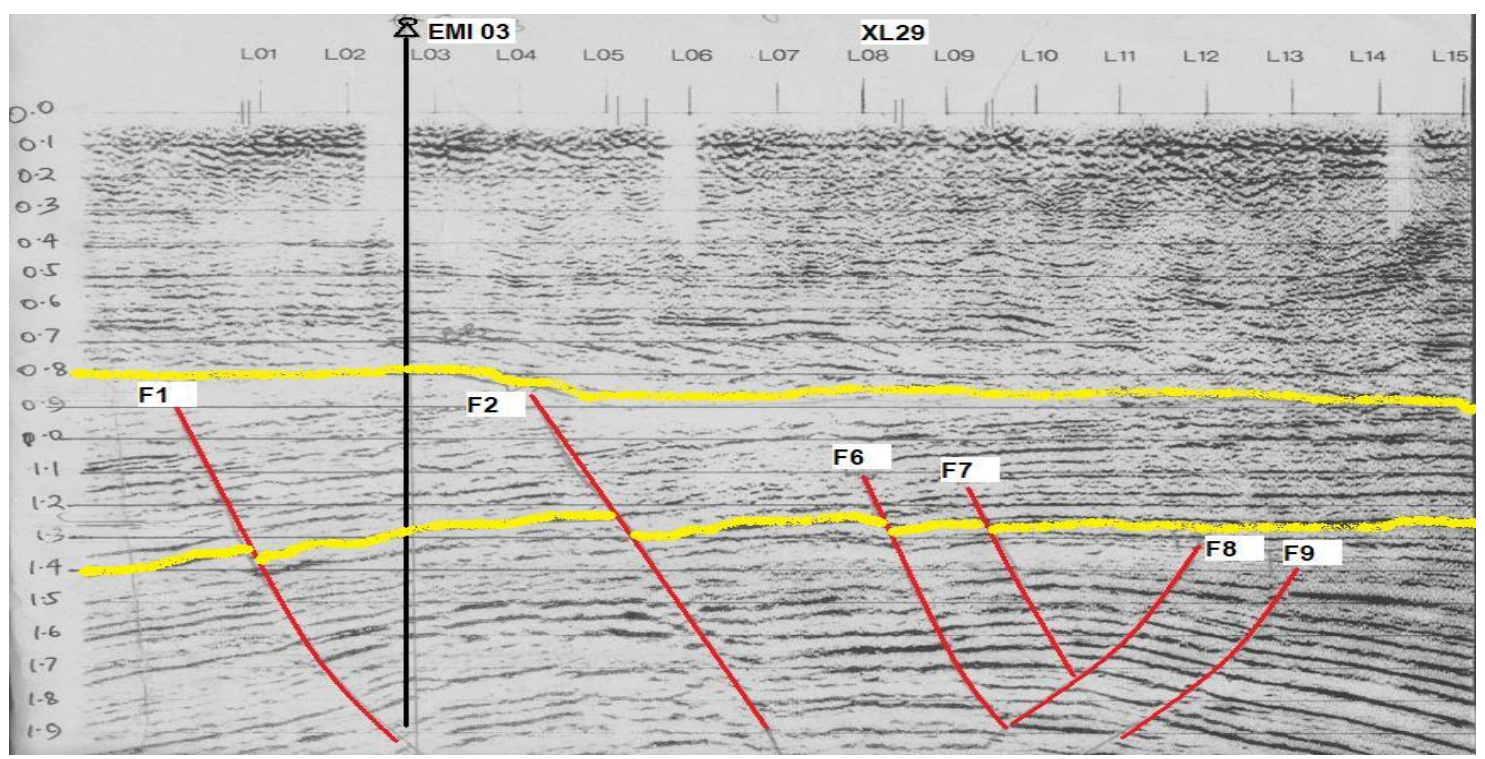

Fig.3: Seismic cross-line 29, showing well 03 and faults picked and horizons 1 and 2

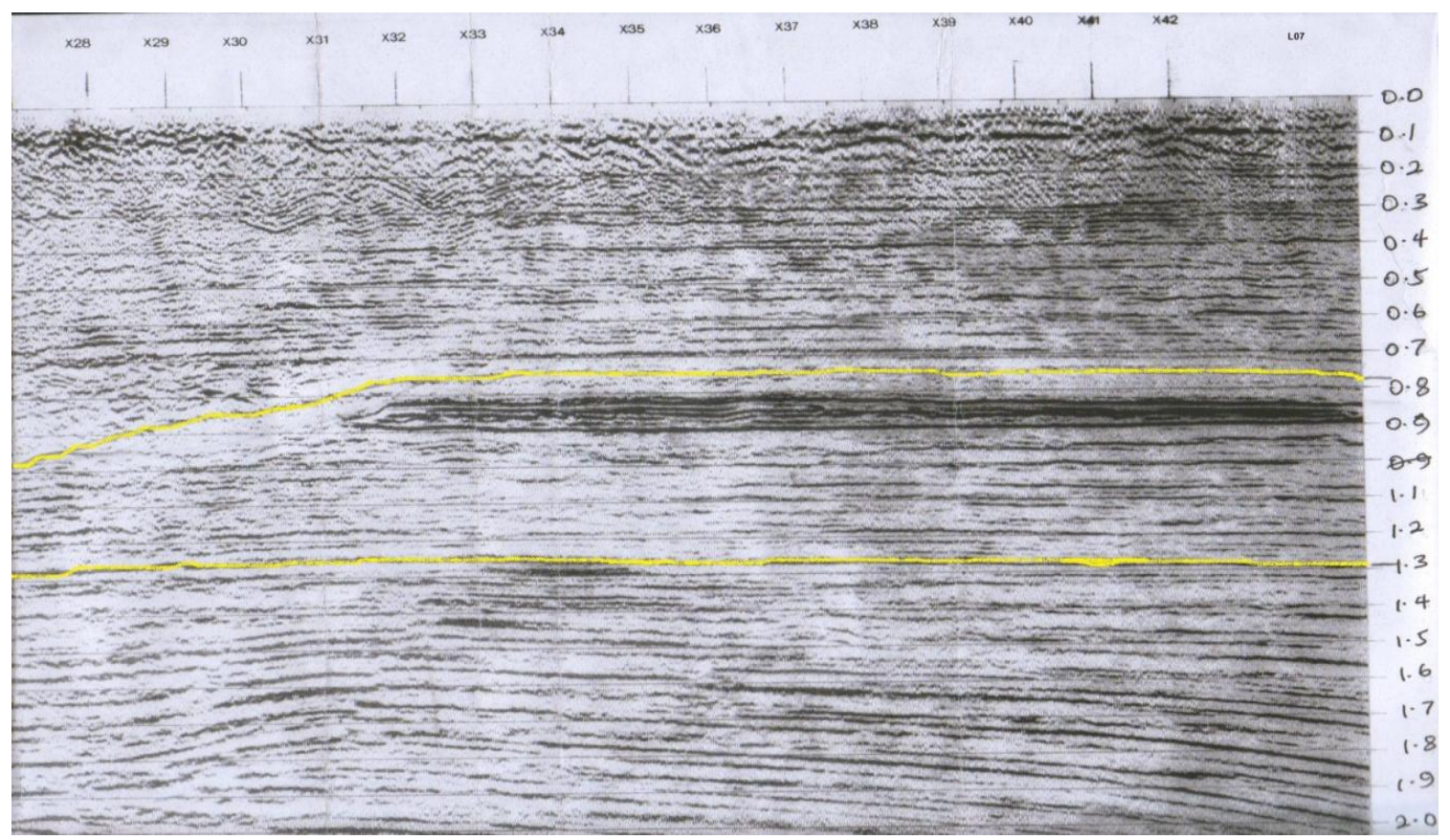

Fig. 4: Seismic inline 07 showing horizons 1 and 2 


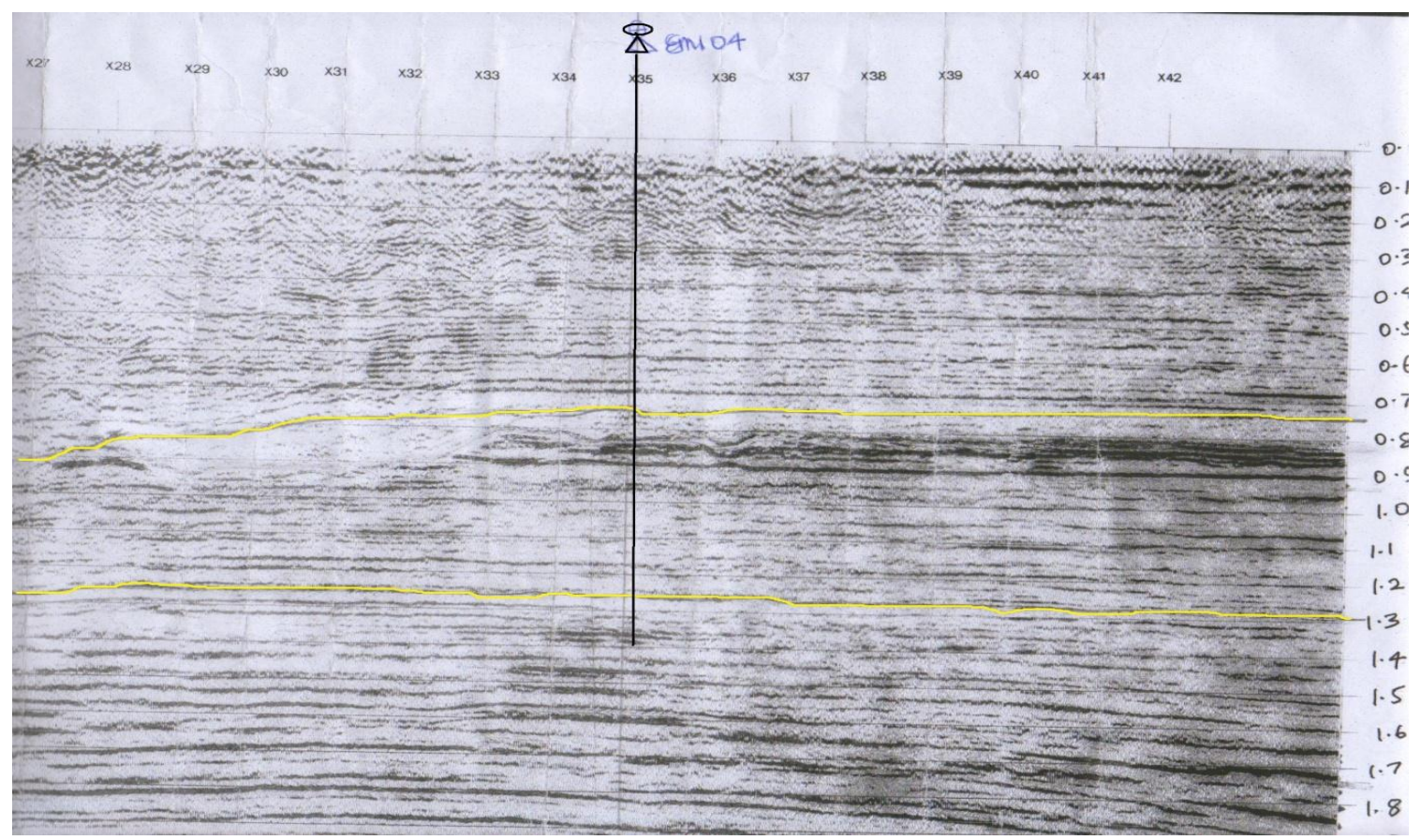

Fig. 5: Seismic inline 09 showing horizons (H) 1 and 2

However, criteria (a) to (d) above were used in picking of the horizons.

A complete set square was used to measure corresponding time and distance of each point on the horizons, and the values obtained were used to generate the maps. Check-shots data were used in the conversion of two-way time to depth. Using the well logs, the tops and bases of reservoir sands A, B and $C$ were picked, while the top of sands $A$ and $C W$ ere used to pick the horizons.
The horizons were picked using the time equivalent of the tops of sands $A$ and $C$ located on the well path (Table 1). The depth of these sand tops were converted to time using the check-shots data, and the nearest, brightest and most continuous reflection were mapped on the in-lines. EMI 4 was generally used as control. Horizon A coincides with a sequence boundary. The two horizons were mapped round the whole seismic volume by Phantoming and Looping.

Table1: Time and depth values of sands A, B and C in all wells.

\begin{tabular}{|l|c|c|c|c|c|c|}
\hline & \multicolumn{2}{|c|}{ SAND A TOP } & \multicolumn{2}{c|}{ SAND B TOP } & \multicolumn{2}{c|}{ SAND C TOP } \\
\hline WELL NO & DEPTH (ft) & TIME (sec) & DEPTH (ft) & TIME (sec) & DEPTH (ft) & TIME (sec) \\
\hline EMI 02 & 2605 & 0.82 & 2690 & 0.85 & 4536 & 1.35 \\
\hline EMI 04 & 2690 & 0.85 & 2750 & 0.85 & 4525 & 1.32 \\
\hline EMI 01 & 2718 & 0.89 & 2960 & 0.99 & 4538 & 1.36 \\
\hline EMI 03 & 2108 & 0.68 & 2975 & 0.95 & 4480 & \\
\hline EMI 05 & 2845 & 0.87 & 3185 & 0.96 & 4393 & \\
\hline EMI 06 & 2960 & 0.92 & 3300 & 1.0 & 4540 & \\
\hline
\end{tabular}


a. Phantoming: this is achieved by folding a point on a fault block and over laying it on another point on either of the preceding or next fault block making sure that the same reflection matches the other and hence, ensuring the continuity of the horizon. This was particularly used when mapping Horizon $B$ which cut across the faults.

b. Looping: also known as tying. This was carried out by folding the in-lines, which already has the horizon mapped, over the cross-lines or vice versa. This was done by first locating the points of intersection of the cross-lines and in-lines and each section is folded at the intersection points and overlaid at the appropriate point of the intersecting lines. This was done to also ensure that the geological surface (reflection) is continuous.

Posting of Faults: After mapping out the faults and the horizons, the faults were posted on the already enlarged base map on a tracing paper. This was carried out by mapping the fault heaves of the $C$ sand horizon; it is the only horizon that runs across the faults. The hanging and foot walls of the faults (the throw) were measured with reference to the in-lines. Posting the faults on the map also helped with better identifying, correlating and renaming the faults on the seismic sections. There were both synthetic faults (dipping south) and the antithetic faults (dipping north). The general trend of the faults was NE-SW (Figs 4 and 5).

Generation of Maps: About five different types of maps were generated to aid in the data interpretation. These maps include: Time Structure map, Depth structure map, Thickness map, Velocity maps and Interval velocity maps. Representatives of these maps are shown in figures 7 to 9 .

Seismic structural maps were generated to evaluate the geometry of the mapped horizons. These maps also give an interpreter a 3D perspective of the mapped surfaces. The corresponding time values of the two horizons on all the cross-lines were picked with the use of the in-lines to generate the time map. The time axis was calibrated on the section, every 0.1 second measured $0.9 \mathrm{~cm}$ on the meter rule, $1 \mathrm{~cm}$ equalled $0.105 \mathrm{sec}$, this was added to the preceding time and then multiplied by a thousand thereby converting the time in seconds to milliseconds. After measuring all the time values, all the values were posted on the base map for contouring.

The time values of the two horizons were converted to depth with the use of the polynomial function - $y=$ $493.36 x 2+2729.3 x+1.7974$ which was generated from the check-shot data provided (fig 6). The values obtainedweres used to produce the structure contoured maps.

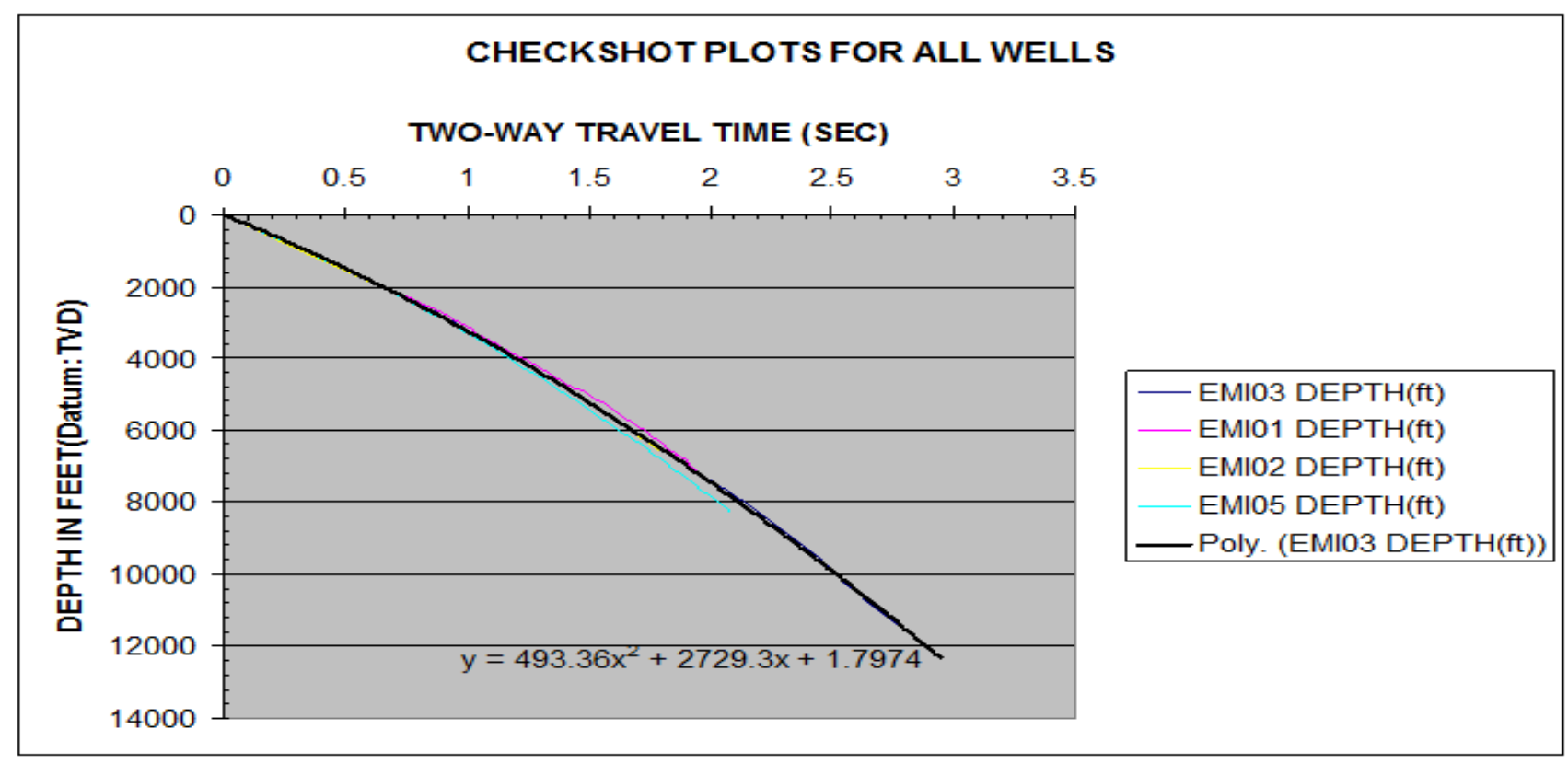

Fig 6: Check-shot data plot for all the wells. 
Litho-logy Delineation from Well Logs: The gamma ray log was used in identifying the litho-logy penetrated by the wells. A shale base line was first established. Maximum deflection of the log signature to the right of the shale base line was interpreted as shale while maximum deflection to the left of the shale base line was interpreted as sandstone. Intermediate values were interpreted as sandy shale or shaly sands. For the resistivity log, deflections to the left were interpreted as low resistivity or high conductivity. Saline water formations are highly conductive while hydrocarbon prone areas have high resistivity.

Identification of Prospects: After contouring had been completed and necessary amendments done, the prospects were identified. This was done by identifying structural traps or closures found around fault blocks. The new Prospects (leads) are areas represented on a structural map where hydrocarbons are likely to accumulate. These areas were demarcated as P1, P2 and P3 as seen in (Fig 9b). Figure 9 generally shows representative of the Depth Map of the study area.

The depth values of the first horizon $(\mathrm{H} 1)$, decrease towards the eastern part of the field which gives rise to structural highs at its eastern portion. The depth values of $\mathrm{H} 1$ range from about $2600 \mathrm{ft}$ to about 3500 $\mathrm{ft}$. There are three anticlinal structures - P1, P2 and $\mathrm{P} 3$ in the field but only $\mathrm{P} 1$ and $\mathrm{P} 2$ have hydrocarbon accumulations because of their structural closures. The prospects $\mathrm{P} 1$ and $\mathrm{P} 2$ are a twin anticlinal structure, but most probably unconnected because of the presence of a saddle, an effective saddle. P1 and P2 have been tested; EMI 01 in P1 has an oil-water contact at $2742 \mathrm{ft}$ while EMI 04 in P2 has hydrocarbon-water contact at $2726 \mathrm{ft}$.

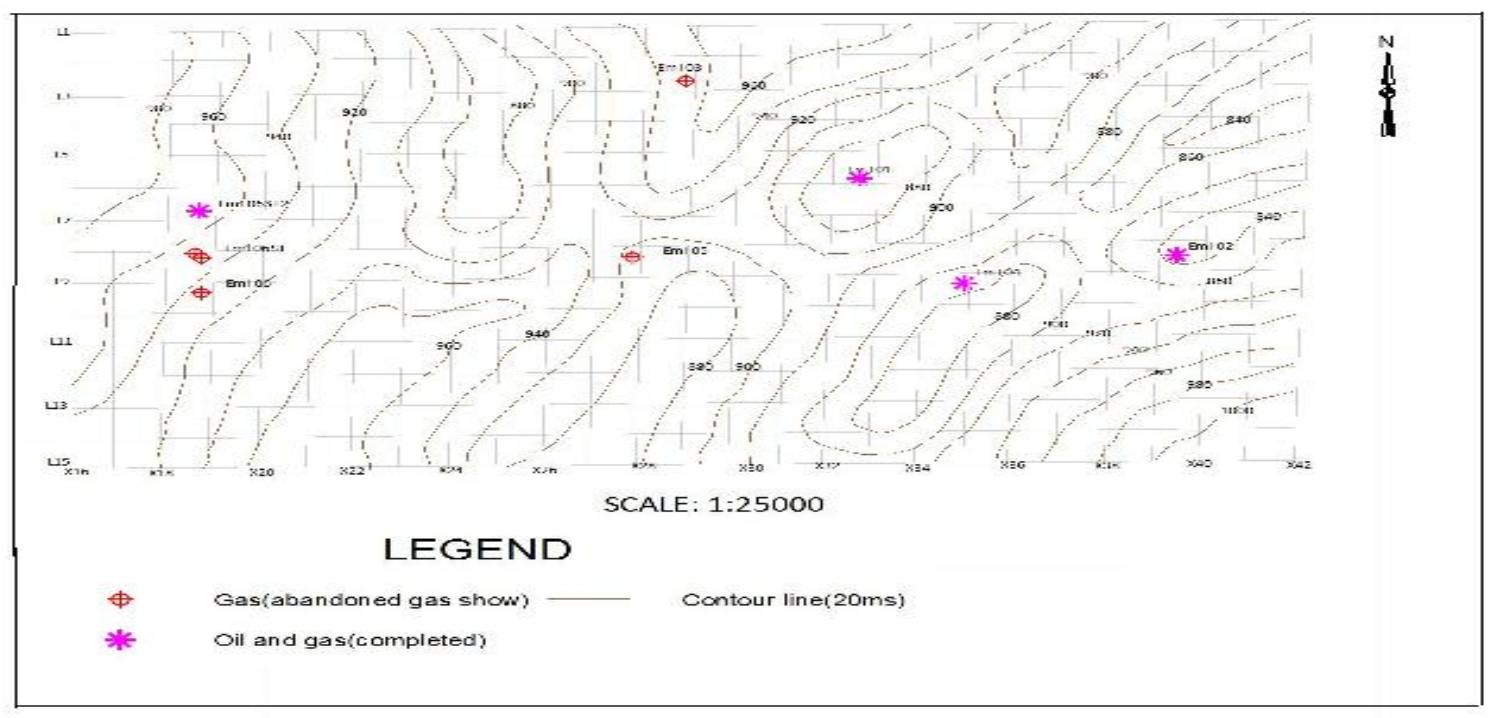

Fig. 7: H1 Time Structure Map 
Am. J. Sci. Ind. Res., 2013, 4(1): 11-21

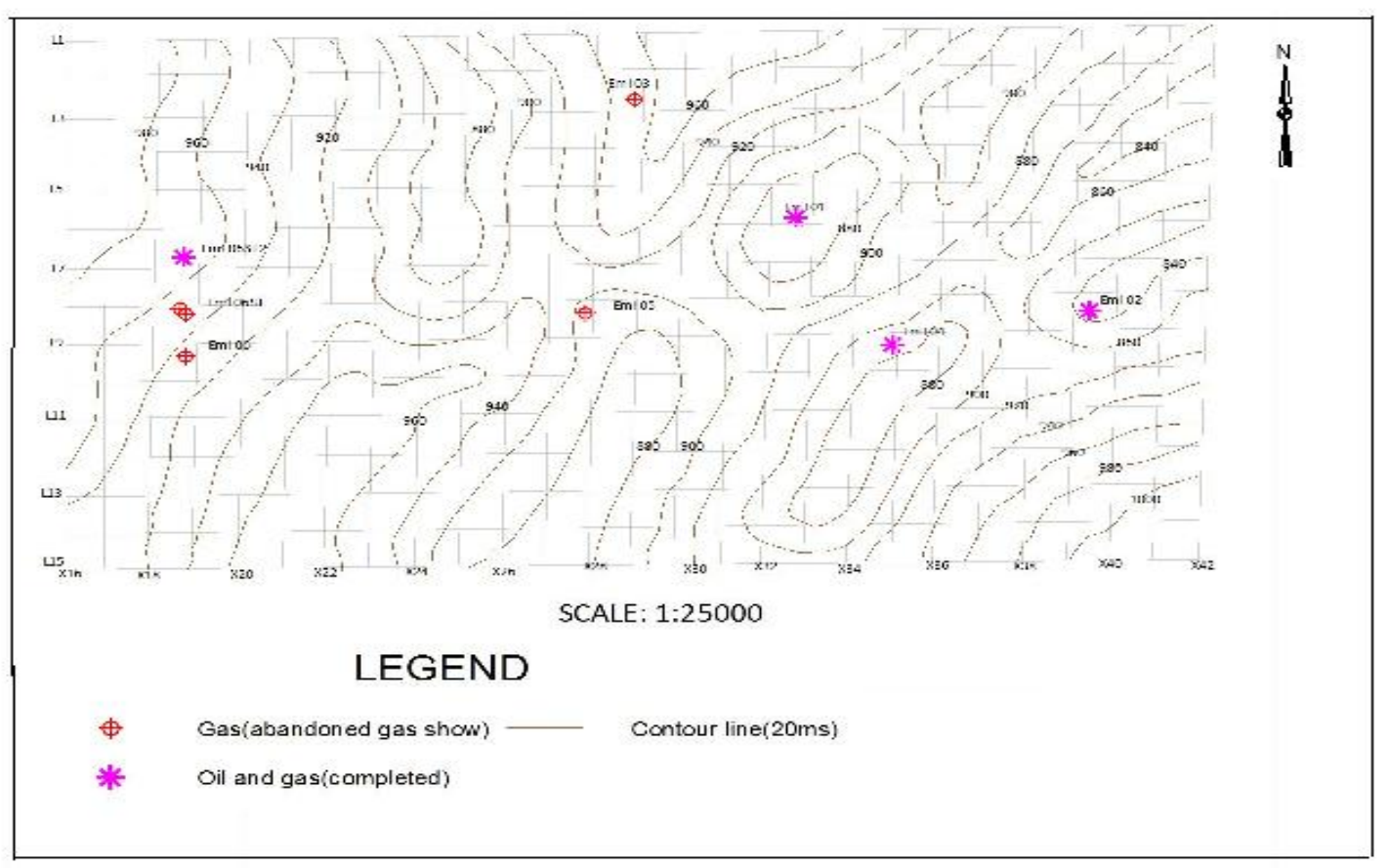

Fig 8: H2 Time Structure Map.

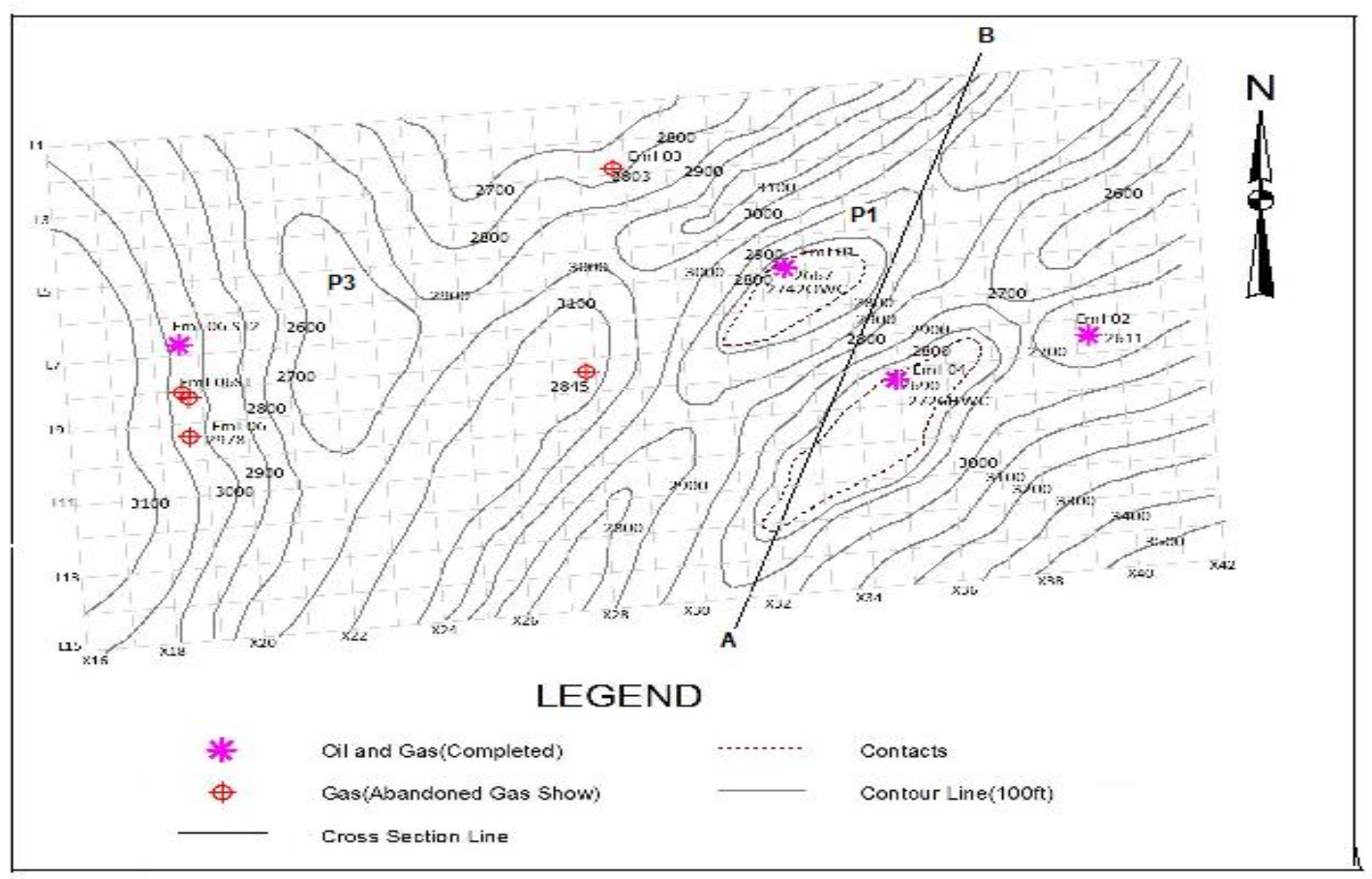

Fig.9a: H1 Depth Structure Map, showing P1, P2 and P3 


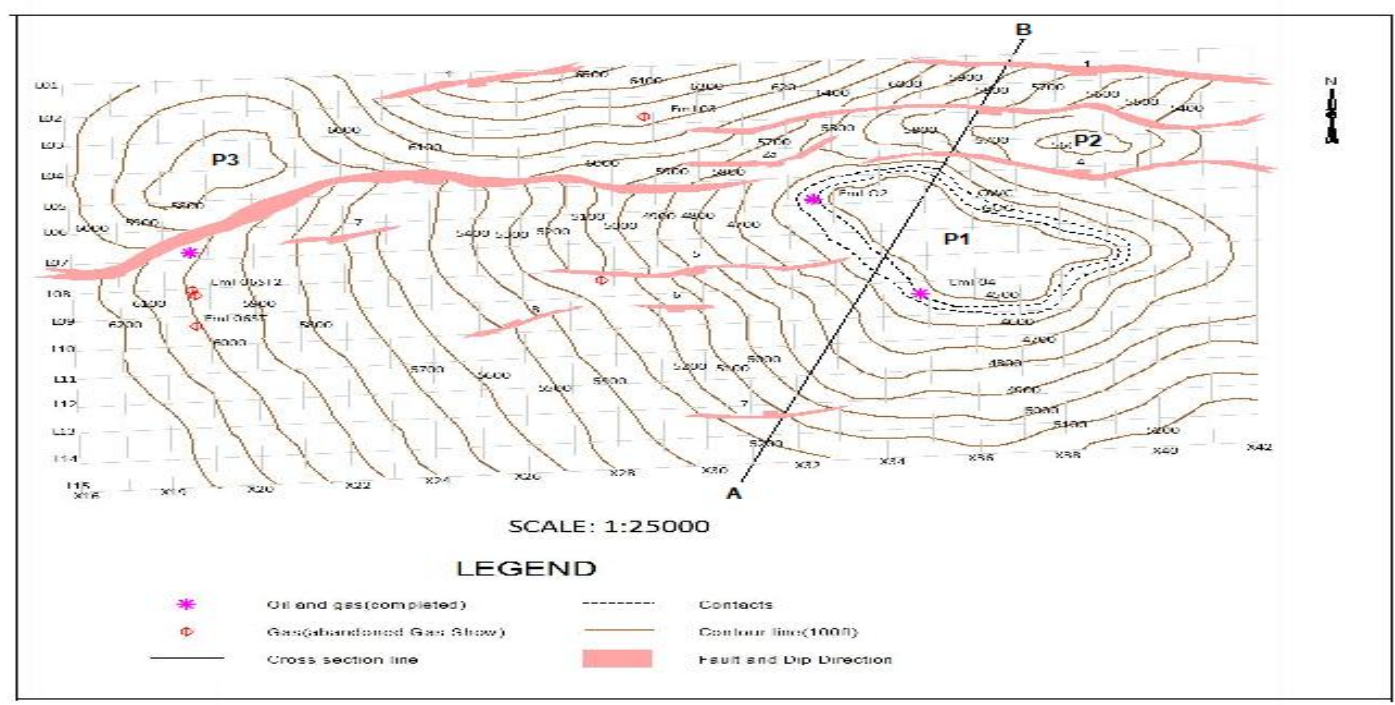

Fig.9: H2 Depth Structure Map showing prospect areas P1, P2 and P3.

Figure 9b on the other hand, shows the Depth Map of the second horizon $(\mathrm{H} 2)$. The depth values decrease from southwest part of the map towards the eastern part of it which results in structural highs around the northeast. $\mathrm{H} 2$ depth values range from about $4600 \mathrm{ft}$ to about $6200 \mathrm{ft}$. The field has three prospect areas labelled P1, P2 and P3. All of these have anticlinal structures that support hydrocarbon accumulation. P1 has a 4-way closure, a rollover anticlinal structure. P2 has a 2-way closure, which was totally fault dependent. P3 has a 3-way closure, supported by a major fault F2. Only prospect P1 has been tested as 3 wells have been drilled, the wells are producing.

Calculation of Reserves: The base map was divided into grids and the area of each grid was calculated to be $1.5 \mathrm{~cm} \times 1.7 \mathrm{~cm}$. It was then converted to meters using the scale $1 \mathrm{~cm}: 25,000 \mathrm{~cm}$, giving $375 \mathrm{~m} \times 425 \mathrm{~m}$, then converted to kilometres, $0.159 \mathrm{sq} \mathrm{km}$. The grids were then counted for the oil, gas and general prospects and multiplied by the box area to get area of prospect. The Gross Rock Volume was then calculated in acre feet. The information in table 2 which was obtained from well log data were used in the calculation of reserve.

Table 2: Petro-physical parameters of the reservoir sands

\begin{tabular}{|c|c|c|c|c|c|c|c|c|c|c|c|}
\hline \multicolumn{12}{|c|}{ EMI_1 Table of Rock Properties } \\
\hline SAND & \multicolumn{2}{|c|}{ TOP } & \multicolumn{2}{|c|}{ BASE } & \multirow[t]{2}{*}{ Contacts } & \multirow[t]{2}{*}{ Gross Interval } & \multirow[t]{2}{*}{ NTG } & \multirow[t]{2}{*}{ Gross Pay } & \multirow[t]{2}{*}{$\Phi$} & \multirow[t]{2}{*}{ Sw } & \multirow[t]{2}{*}{ REMARK } \\
\hline & MD (ft) & TVDSS (ft) & MD (ft) & TVDSS (ft) & & & & & & & \\
\hline C & 4528 & -4477 & 4561 & -4510 & ODT & 33 & 0.88 & 33 & 0.271 & 0.341 & ODT \\
\hline \multicolumn{12}{|c|}{ EMI_2 Table of Rock Properties } \\
\hline SAND & \multicolumn{2}{|c|}{ TOP } & \multicolumn{2}{|c|}{ BASE } & Contacts & Gross Interval & NTG & Gross Pay & $\Phi$ & Sw & REMARK \\
\hline & MD (ft) & TVDSS (ft) & MD (ft) & TVDSS (ft) & & & & & & & \\
\hline $\mathrm{C}$ & 4540 & -4486.5 & 4575 & -4521.5 & -4510.5 & 35 & 0.86 & 24 & 0.239 & 0.46 & OWC \\
\hline \multicolumn{12}{|c|}{ EMI_4 Table of Rock Properties } \\
\hline SAND & \multicolumn{2}{|c|}{ TOP } & \multicolumn{2}{|c|}{ BASE } & Contacts & Gross Interval & NTG & Gross Pay & $\Phi$ & Sw & REMARK \\
\hline & MD (ft) & TVDSS (ft) & MD (ft) & TVDSS (ft) & & & & & & & \\
\hline C & 4531.5 & -4480.5 & 4568.5 & -4517.5 & -4509.5 & 37 & 0.8 & 29 & 0.239 & 0.46 & GOC \\
\hline
\end{tabular}

Where MD is measured depth

TVDSS is true vertical depth Sub Sea

NTG is net to gross

$\mathrm{Sw}$ is water saturation

$\Phi$ is porosity

The following calculations were done to compute the reserve estimate. All the formula used were in

accordance with the Oil and Gas industry and all the abbreviations have been defined accordingly. 
OOIP $=7758 \times A \times h \times \theta \times(1-S w) \times N T G$ barrels

Where OOIP is Original Oil In Place in

7758 is a constant

$h$ is Thickness of oil sand

$\Theta$ is Porosity

$A$ is closure area of the reservoir in acre

Sw is water saturation; 1-Sw is Hydrocarbon saturation

NTG is Net to Gross i.e. percentage ratio of reservoir sand to the total rock volume.

\section{OGIP $=43560 \times A \times h \times \theta \times(1-S w) \times N T G$}

Where OGIP is Original Gas In Place in Standard Cubic Feet (scf)

The Stock Tank Oil and Gas In Place (STOIP and STGIP respectively) could not be estimated because the field data provided did not include recovery factor and Formation Volume Factor (Boi) which is also known as the shrinkage factor.

\section{HORIZON 2 (SAND C)}

$$
\begin{aligned}
& \text { Prospect 1: } \\
& \text { AREAgas }=0.159 \text { sqkm } \times 13.5 \text { grids } \\
& =2.15 \mathrm{sqkm} \\
& \approx 531.28 \text { acres } \\
& \text { Thickness of Gas sand }=37 \mathrm{ft} \\
& \text { GRVgas }=531.28 \times 37 \mathrm{ft} \\
& =19657.36 \text { acre } \mathrm{ft} \\
& \text { AREAoil }=0.159 \text { sqkm } \times 20 \text { grids } \\
& =3.18 \mathrm{sqkm} \\
& \approx 765.79511 \text { acres } \\
& \text { Thickness }(\mathrm{OWC})=35 \mathrm{ft} \\
& \text { GRVoil }=765.79511 \times 35 \mathrm{ft} \\
& =27502.83 \text { acre } \mathrm{ft} \\
& =7845.47 \text { acre } \mathrm{ft}
\end{aligned}
$$

\section{Prospect 2}

$\mathrm{P} 2=11.5$ grids

$=0.159 \mathrm{sqkm} \times 11.5$

$=1.8285 \mathrm{sqkm}$

$\approx 451.83219$ acres

Thickness $=37 \mathrm{ft}$ (assuming a uniform thickness)

$\mathrm{GRV}=451.83219 \times 37$

GRV P2 $=16717.791$ acres $\mathrm{ft}$

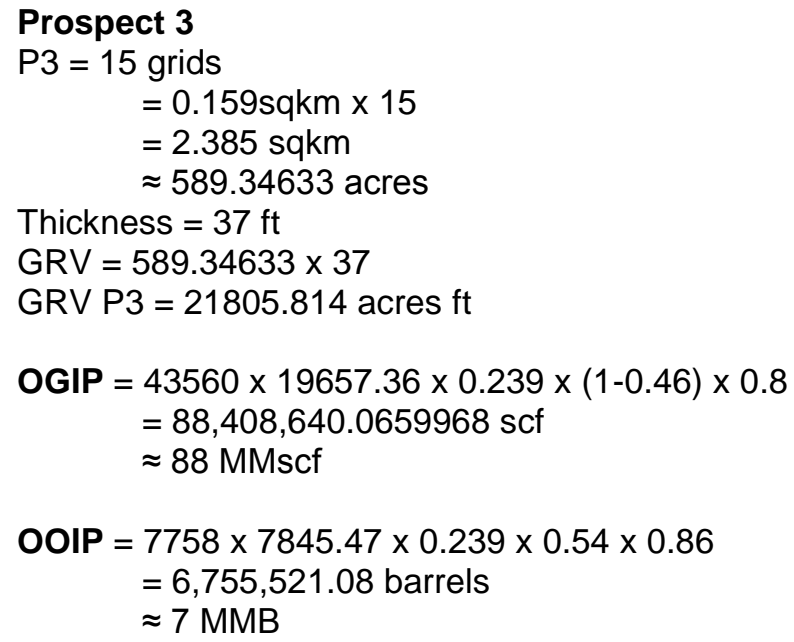

The structural closure on the eastern part of the $\mathrm{H} 2$ structure map correlates with the hydrocarbon reservoirs on the well logs - EMI 01, EMI 02 and EMI 04.

The oil reserve was estimated as OOIP to be about 7 million barrels while the gas reserve was estimated as OGIP to be about 88 MMscf.

\section{CONCLUSION}

The seismic and petro-physical interpretation of EMI field shows typical structural features of the Niger Delta which includes the roll over anticlines and growth faults. EMI field is a promising field with good structures for hydrocarbon accumulation.

The extensive faults F2, F3 and F4, which were structure building faults, support suspected hydrocarbon prospects (P2 and P3) which can be explored in the future.

The deeper of the two horizons mapped have better structures for hydrocarbon accumulation with supporting growth faults. The shallower horizon, $\mathrm{H} 1$ does not have any faults intersecting it. The two horizons marked the tops of reservoir sands in the field and they both also correspond to sequence boundaries.

The petro-physical values - the porosity, Net to Gross, Water saturation, hydrocarbon saturation) that were calculated from the POWERLOG software are almost ideal for the Niger Delta reservoir sands with average porosity values of 0.25 , water saturation of 0.42 and average Net to Gross value of 0.85 . The lower the water saturation, the higher the hydrocarbon saturation in the reservoir sand, also the 
higher the net to gross value, the higher the hydrocarbon saturation.

\section{REFERENCES}

Bryant, I.D. (1996) The Application of Physical Measurements to Constrain Reservoir-Scale Sequence Stratigraphic Models. In: Howell, J.A. \& Aitken, J.F (eds). High Resolution Sequence Stratigraphy: Innovations and Applications. Geology Society Special Publication 104. 51-64

Chukwueke, C.C. (1997). Factors controlling hydrocarbon distribution in the central swamp depobelt of the Niger Delta. Nigerian Association of Petroleum Explorationists Bulletin. Volume 12, pp 41-45.

Doust, H. and Omatsola, E. (1990). Niger Delta: In J.D. Edwards P.A. Santogrossi, eds divergent/passive margin basins: American Association of Petroleum Geologists Bulletin Memoir 48, pp 201-328.

Kulke, H. (1995). Nigeria, in Kulke, H., ed., Regional Petroleum Geology of the World. Part II: Africa,
America, Australia and Antarctica: Berlin, Gebruder Borntraeger, pp 143-172.

Nwachukwu, J.I. and Chukwurah, P.I. (1986). Organic matter of Agbada Formation, Niger Delta, Nigeria: American Association of Petroleum Geologists Bulletin, Volume 70, pp 48-55.

Petroconsultants, (1996a): Petroleum exploration and production database: Houston, Texas.

Sheriff, R.E. and Geldart, L.P., (1995): Exploration seismology: Press syndicate of the University of Cambridge, 592p.

Short, K.C. and Stauble, A.J. (1967). outline of Geology of Niger Delta: American Association of Petroleum Geologists Bulletin, Volume 51, pp 761-799.

Weber, K.J. and Daukoru, E.M. (1975). Petroleum geology of the Niger Delta, $9^{\text {th }}$ World Petroleum Congress Proceedings, Tokyo. Volume2, pp 209-221. 